\title{
Management of spontaneous extramedullary spinal haematomas: results in eight patients after MRI diagnosis and surgical decompression
}

\author{
J J Langmayr, M Ortler, A Dessl, K Twerdy, F Aichner, S Felber
}

\begin{abstract}
Spinal cord compression due to extradural and subdural haemorrhage is a neurosurgical emergency. Differences in clinical presentation in relation to localisation of the haematoma, value of MRI as a diagnostic tool, surgical treatment, and prognosis were investigated in a retrospective case series of eight patients with extradural ( $n=$ four) and subdural ( $n=$ four) haematomas. Results of MRI were compared with operative findings and proved to be of high sensitivity in defining the type of bleeding and delineating craniocaudal extension and ventrodorsal location. Surgical treatment by decompressive laminectomy, haematoma evacuation, and postoperative high dose corticosteroids resulted in resolution of symptoms in five patients and improvement in the clinical situation in two patients. One patient with a chronic subdural haematoma had a second operation because of arachnoidal adhesions. One patient presented with a complete cord transection syndrome due to an acute subdural haematoma and remained paraplegic. It is concluded that prompt, reliable, and non-invasive diagnosis by MRI leads to efficient surgical treatment and a favourable outcome in this rare condition.
\end{abstract}

$(\mathcal{F}$ Neurol Neurosurg Psychiatry 1995;59:442-447)

Universitätsklinik für

Neurochirurgie,

Innsbruck, Austria

$\mathrm{J} \mathrm{J}$ Langmayr

M Ortler

K Twerdy

Gemeinsame

Einrichtung für

Magnetresonanztomo-

graphie und

-spektroskopie,

Innsbruck, Austria

A Dessl

F Aichner

$S$ Felber

Correspondence to:

Dr J J Langmayr

Universitätsklinik für

Neurochirurgie, 35,

Anichstrasse, Innsbruck,

Anichstrasse,

Received 2 February 1994 and in revised form

15 May 1995

Accepted 5 June 1995
Keywords: spinal haematomas; surgical decompression; magnetic resonance imaging

Spontaneous spinal haematomas are rare and represent neurosurgical emergencies because they may lead to spinal cord compression. ${ }^{12}$ Whereas a relatively large body of medical literature exists regarding extradural spinal haematomas, ${ }^{3-9}$ only a few reports on subdural spinal haematomas have appeared..$^{10-12}$

We analyse the clinical presentation, MRI results, intraoperative findings, and outcome in a series of eight patients with extradural and intradural extramedullary spinal haematomas. The discussion focuses on pathogenetic factors of the bleeding; differences in clinical presentation between extradural and intradural haematomas; the role of MRI compared with CT and myelo- graphy for the investigation of patients with this rare disorder; and strategies for surgical treatment.

\section{Methods}

This case series includes eight patients with spontaneous extra-axial spinal haematomas seen between 1988 and 1993 at the Neurochirurgische Universitätsklinik, Innsbruck, Austria, an academic neurosurgical unit which also serves as the primary referral centre for all patients with suspected central nervous disease requiring surgery. Data regarding history and signs were gathered retrospectively by analysis of patient records.

Neuroradiological investigation included MRI in all patients; five patients also underwent myelography and CT. A 1.5 Tesla unit (Magnetom Siemens, Erlangen, Germany) was used for MRI. The imaging protocol consisted of $T 1 \quad(T R=550 \mathrm{~ms} / \mathrm{TE}=15 \mathrm{~ms})$ images and proton density/T2 weighted double spin echo sequences (TR $=1800 \mathrm{~ms}$ ) $\mathrm{TE}=15$ and $90 \mathrm{~ms}$ ) in a sagittal orientation, followed by transverse $\mathrm{T} 1$ weighted sequences. All patients were examined with a T2 weighted gradient echo sequence ( $T R=$ $400 \mathrm{~ms} / \mathrm{TE}=18 \mathrm{~ms} /$ alpha $=15^{\circ}$ ) in the transverse orientation.

All patients underwent decompressive laminectomy at the levels indicated by preoperative imaging techniques and complete evacuation of the haematoma. Specimens were sent for histological examination. Whenever a well defined membrane or other signs of clot organisation were found at surgery and confirmed by histology a haematoma was classified as chronic. All patients received a postoperative short course of antibiotics and high dose dexamethasone.

All patients were available for follow up three to six months after surgery.

\section{Case series}

CLINICAL PRESENTATION

Table 1 gives a summary of the clinical data. Eight patients (three men, five women) with a spontaneous extradural (four patients) or subdural (four patients) spinal haematoma were seen in six years. Mean age was 58 (range 19 to 73 ) years. Seven patients were older than 50.

Five of the eight patients had a history of anticoagulation. Prothrombin time at presen- 
tation in these patients was above $30 \%$ (normal range $70-110 \%$ ). One patient reported a daily intake of $500 \mathrm{mg}$ acetylsalicylic acid.

Nearly all patients presented with back pain as the leading symptom (patients 1 to 7 ). Sometimes the pain was irradiating into the extremities mimicking radicular pain. True radicular pain was present in only one patient, with an acute extradural haematoma (patient 6). In chronic haematomas, a progressive paraparesis, perceived by the patients as "tiredness" or "weakness" was the leading symptom in about half of the patients (patients 3 and 8 ).

Although patient numbers are low, a certain difference in history between acute and chronic lesions was noted. Pain in acute extradural haematomas was present for about 35 hours (range 17-72 hours) before clinical signs appeared. In the only patient with a true acute subdural haematoma, back pain was present within minutes after the rupture of an aneurysm of a radicular artery. Signs of incomplete cord transection were noted 17 hours later (patient 7). Another patient (patient 4) with a complete transection 12 hours after a coeliac ganglion block showed signs of new haemorrhage into an older haematoma at surgery. If this patient is included in the acute subdural haematoma group, this type of haematoma in our series becomes clinically appreciable slightly earlier than the extradural counterpart.

In the patient with a chronic extradural haematoma (patient 3), weakness in both legs was the first symptom and pain was present for only a few hours before admission. In all patients with a chronic subdural haematoma (patients 4, 5, 8), the time between onset of symptoms and appearance of signs was about 15 days (10-21 days). As pointed out earlier, weakness occurred before pain as a symptom in chronic lesions.

Differential diagnosis between extradural and intradural haematoma on clinical examination alone was not possible. Signs of a partial or complete spinal cord transection syndrome were present in seven of eight patients. Only one patient (patient 6 with an acute extradural haematoma) exhibited signs of an isolated radicular lesion. In all patients the clinical level of spinal cord transection correlated with the results of the imaging studies. Bladder dysfunction was present in two patients.

\section{IMAGING}

The table summarises the neuroradiological data. An initial CT examination without contrast agent was performed in five patients and led to the diagnosis of an epidural haematoma in only one. Thoracic intraspinal haematomas in two patients were not detected on CT, the diagnosis of two lumbar haematomas within the spinal canal remained inconclusive because of isointensity of the haematoma.

Myelography and postmyelography CT were performed in three patients and delin- eated the site of cord compression but were not specific.

Magnetic resonance imaging correctly identified the presence and delineated the cervicocaudal extension of a haematoma in all patients; MRI also distinguished between extradural and subdural haematoma in all but one patient. This patient (table, patient 7) had a combined subdural and subarachnoid haemorrhage.

\section{FINDINGS AT SURGERY}

Four epidural and four subdural haematomas were evacuated. Macroscopic and histological signs of chronic disease were present in one patient in the epidural haematoma group and in two patients with a subdural haematoma. A bleeding source was identified only in the patient with aneurysm of a radicular artery (patient 7). The rupture of the aneurysm caused a combined subarachnoid/subdural haemorrhage. In the other patients no bleeding source could be identified. Meninges in patient 8 were thickened.

\section{POSTOPERATIVE COURSE}

The only surgical complication was a CSF fistula in patient 5 . In the same patient a second intervention was performed after three weeks because of subarachnoid adhesions at the site of the primary haematoma. Histological examination of the thickened meninges of patient 8 showed neoplastic infiltration of the meninges. Four patients with an epidural haematoma (patients $1,3,6,7$ ) and one with a chronic subdural haematoma (patient 5) recovered completely. Two patients (2 and 8 ) regained walking capability after surgery. One (patient 4 ) with a complete transection syndrome showed no clinical improvement after surgery. No deaths related to surgery were recorded.

\section{Discussion}

\section{EPIDEMIOLOGY}

The entity is rare. The true incidence of spontaneous extramedullary spinal haematomas is not known. A few hundred cases of extradural and about 50 cases of subdural haematomas have been reported. ${ }^{311}$ Male to female ratio was 1:1 for extradural and 1:3 for subdural haematomas. ${ }^{2}$ In larger series a male predominance for extradural and a female predominance for subdural haematomas were reported. ${ }^{2}$ Our youngest patient was 19 years old. All other patients were of advanced age.

\section{PATHOGENESIS}

Pathogenetic mechanisms leading to a spontaneous spinal haematoma are incompletely understood. Data from the medical literature suggest that trauma including iatrogenic injuries during lumbar puncture or epidural anaesthesia, ${ }^{13}$ and primary and secondary coagulopathies such as anticoagulant therapy are important pathogenetic factors contributing to the formation of a spinal extradural haematoma. The role of minor trauma related to activities of daily living is contro- 


\begin{tabular}{|c|c|c|c|c|c|c|c|c|}
\hline $\begin{array}{l}\text { Patient } \\
\text { No }\end{array}$ & $\begin{array}{l}\text { Age, } \\
\text { sex }\end{array}$ & Pathogenesis & Symptoms & Signs & $\begin{array}{l}\text { Time between } \\
\text { onset of } \\
\text { symptoms and } \\
\text { appearance of } \\
\text { signs }\end{array}$ & MRI findings & Surgical diagnosis & Outcome \\
\hline 1 & $63, M$ & AC & $\begin{array}{l}\text { Back pain } \\
\text { irradiating in } \\
\text { both legs }\end{array}$ & $\begin{array}{l}\text { Absent on gross } \\
\text { examination }\end{array}$ & $\begin{array}{l}72 \mathrm{~h} \text { (= time } \\
\text { between onset } \\
\text { of symptoms } \\
\text { and diagnosis) }\end{array}$ & $\begin{array}{l}\text { Obliteration of the } \\
\text { spinal canal to } \\
\text { about } 50 \% \text { at Th } \\
11-\mathrm{L} 3 \text {, isointense } \\
\text { in T1, } \\
\text { inhomogeneously } \\
\text { hypointense in } \\
\text { PD and T2 }\end{array}$ & $\begin{array}{l}\text { Acute extradural } \\
\text { haematoma }\end{array}$ & $\begin{array}{l}\text { Complete } \\
\text { recovery }\end{array}$ \\
\hline 2 & $60, F$ & AC, LP & $\begin{array}{l}\text { Back pain and } \\
\text { pain } \\
\text { irradiating in } \\
\text { both legs }\end{array}$ & $\begin{array}{l}\text { Transection } \\
\text { Th } 8,2 \text { h post } \\
\text { LP }\end{array}$ & $\begin{array}{l}16 \mathrm{~h}(2 \mathrm{~h} \text { post } \\
\mathrm{LP})\end{array}$ & $\begin{array}{l}\text { Lesion ventrally } \\
\text { located at Th } \\
7-9 \text {, isointense in } \\
\text { T1 and mixed } \\
\text { hypo- and } \\
\text { hyperintense in } \\
\text { PD and T2 }\end{array}$ & $\begin{array}{l}\text { Acute extradural } \\
\text { haematoma }\end{array}$ & $\begin{array}{l}\text { Incomplete } \\
\text { recovery, walks } \\
\text { alone }\end{array}$ \\
\hline 3 & $73, \mathrm{~F}$ & $\mathrm{AC}$ & $\begin{array}{l}\text { "Tiredness" in } \\
\text { both legs, } \\
\text { sudden pain in } \\
\text { thoracolumbar } \\
\text { region before } \\
\text { admission }\end{array}$ & Transection & 14 days & $\begin{array}{l}\text { Ventral lesion of } \\
\text { low signal } \\
\text { intensity in } T 1, \\
P D \text { and } T 2\end{array}$ & $\begin{array}{l}\text { Chronic } \\
\text { extradural } \\
\text { haematoma }\end{array}$ & $\begin{array}{l}\text { Complete } \\
\text { recovery }\end{array}$ \\
\hline 4 & $54, M$ & $\begin{array}{l}\text { Pancreatic } \\
\text { carcinoma, } \\
\text { block of } \\
\text { coeliac } \\
\text { ganglion }\end{array}$ & $\begin{array}{l}\text { Chronic pain, } \\
\text { probably related } \\
\text { to primary } \\
\text { disease }\end{array}$ & Transection Th 12 & $\begin{array}{l}12 \mathrm{~h} \text { post coeliac } \\
\text { ganglion block }\end{array}$ & $\begin{array}{l}\text { Ventral lesion, } \\
\text { slightly } \\
\text { hyperintense in } \\
\text { T1 }\end{array}$ & $\begin{array}{l}\text { Subacute } \\
\text { subdural } \\
\text { haematoma } \\
\text { (in part } \\
\text { subarachnoidal) }\end{array}$ & $\begin{array}{l}\text { Paraplegic, no } \\
\text { walking ability }\end{array}$ \\
\hline 5 & $63, F$ & $\mathrm{AC}$ & $\begin{array}{l}\text { Back pain for } \\
3 \text { weeks, bladder } \\
\text { dysfunction for } \\
2 \text { days }\end{array}$ & Transection C 5 & 21 days & $\begin{array}{l}\text { Lesion } \\
\text { mediolaterally } \\
\text { C6 and second } \\
\text { lesion } \\
\text { dorsolaterally Th } \\
1-5 \text { isointense in } \\
\text { T1 and T2, higher } \\
\text { in PD }\end{array}$ & $\begin{array}{l}\text { Chronic subdural } \\
\text { haematoma }\end{array}$ & $\begin{array}{l}\text { Complete } \\
\text { recovery. 2nd } \\
\text { intervention } \\
3 \text { weeks later: } \\
\text { subarachnoidal } \\
\text { adhesions }\end{array}$ \\
\hline 6 & $73, \mathrm{M}$ & ASA & $\begin{array}{l}\text { Sudden } \\
\quad \text { cervico- } \\
\text { brachialgia }\end{array}$ & $\begin{array}{l}\text { C } 7 \text { radicular } \\
\text { lesion including } \\
\text { triceps paresis }\end{array}$ & $17 \mathrm{~h}$ & $\begin{array}{l}\text { Dorsally C2-6, } \\
\text { isointense in } T 1 \\
\text { and } T 2 \text {, of low } \\
\text { intensity in PD }\end{array}$ & $\begin{array}{l}\text { Acute extradural } \\
\text { haematoma }\end{array}$ & $\begin{array}{l}\text { Complete } \\
\text { recovery }\end{array}$ \\
\hline 7 & $59, \mathrm{~F}$ & & $\begin{array}{l}\text { Frontal headache, } \\
\text { followed by } \\
\text { back pain }\end{array}$ & $\begin{array}{l}\text { Mild meningism, } \\
\text { incomplete } \\
\text { transection } \\
\text { Th } 7-8\end{array}$ & $17 \mathrm{~h}$ & $\begin{array}{l}\mathrm{C} 6 / 7 \text { and Th5/6, } \\
\text { isointense in T1 } \\
\text { and PD, partially } \\
\text { hyperintense on } \\
\text { T2 }\end{array}$ & $\begin{array}{l}\text { Acute subdural } \\
\text { and } \\
\text { subarachnoid } \\
\text { haematoma, } \\
\text { aneurysm } \\
\text { radicular artery } \\
\text { Th 8 }\end{array}$ & $\begin{array}{l}\text { Complete } \\
\text { recovery }\end{array}$ \\
\hline 8 & $19, F$ & $\begin{array}{c}\text { Repeated LP, } \\
\text { gliomatosis } \\
\text { of meninges }\end{array}$ & $\begin{array}{l}\text { Slowly progressing } \\
\text { weakness in } \\
\text { both legs }\end{array}$ & $\begin{array}{l}\text { Flaccid } \\
\text { paraparesis, } \\
\text { bladder } \\
\text { dysfunction }\end{array}$ & 10 days & $\begin{array}{l}\text { Subacute } \\
\text { haematoma, } \\
\text { isointense in T1, } \\
\text { PD, T2 images }\end{array}$ & $\begin{array}{l}\text { Chronic } \\
\text { subdural } \\
\text { haematoma }\end{array}$ & $\begin{array}{l}\text { Incomplete } \\
\text { recovery, walks } \\
\text { with help; } \\
\text { histology: } \\
\text { gliomatosis of } \\
\text { meninges }\end{array}$ \\
\hline
\end{tabular}

AC = Anticoagulants ASA = acetylsalicylic acid $\mathrm{LP}=$ lumbar puncture.

versial. ${ }^{23}$ Excessive blood pressure surges in the valveless epidural veins during coughing and straining, ${ }^{3}$ axial movement of the thecal sac, ${ }^{14}$ and tearing of epidural veins during acute disc disruption as they pass through the thin membrane overlying the posterior longitudinal ligament ${ }^{15}$ have all been implicated in minor trauma related extradural bleeding. None of our patients had a history of major trauma. All patients with an extradural haematoma were under anticoagulant treatment or reported a heavy use of platelet aggregation inhibitors. No data exist on the excursions of blood vessels within the spinal canal during body movements. Increased vessel friability and anticoagulation may lead to a situation in which body excursions cause a disruption of the vessel wall and haematoma formation. Limitation of haematomas within three spinal segments in most patients might be due to the venous origin of the bleeding, the counter pressure exerted by structures within the spinal canal, or unknown coagulation enhancing factors within the spinal canal.

Pathogenetic factors associated with spinal subdural haemorrhage are similar to those reported for extradural haematomas. ${ }^{1011}$ Lumbar puncture in the presence of coagulopathies is a known cause. Major spinal trauma is seldom associated with spinal subdural haematomas. In our patients a pancreatic carcinoma, gliomatosis of the meninges, anticoagulation, and repeated lumbar punctures were associated with the bleeding. Vascular malformations can cause a subarachnoid haemorrhage with subsequent disruption into the subdural space.

CLINICAL PRESENTATION

In acute haematomas back pain was the first symptom, whereas in chronic haematomas weakness usually preceded pain by several 
weeks. Eventually pain was the reason for seeking medical help in all but one patient.

Duration of history was different for acute and chronic lesions. Patients with acute haematomas had a history of roughly one day, patients with chronic haematomas had a history of about two weeks.

Acute subdural haematomas were noted slightly earlier (after several hours) than acute extradural haematomas (after one day). An extradural accumulation of blood might lead to cord compression later due to the dampening effect of the thecal sac fixed within the spinal canal by ligaments and the dural nerve root sheets leaving the canal. Whether blood components themselves act as toxic factors impairing spinal cord function earlier in subdural than in extradural haematomas is not clear.

In agreement with other reports 231011 the clinical examination gave no hint regarding the nature of the lesion. All patients presented with signs of spinal cord or nerve root compression possibly due to an extra-axial spinal pathology.

The strongest factor favouring a haematoma in the differential diagnosis was a history of anticoagulation. The absence of signs of infection in all patients and the presence of signs at spinal levels where primary manifestation of degenerative spinal disease is rare in six of eight patients further restricted differential diagnosis.

\section{IMAGING}

As pointed out by Johnston modern imaging reduces the need to make a diagnosis at the bedside. ${ }^{1}$ Myelography was the diagnostic standard for decades and demonstrates cord compression but has a low specificity. In the case of a complete blockage myelography is unable to show the entire craniocaudal extension of the space occupying lesion. To the surgeon approaching a spinal lesion a myelogram still gives vital information regarding anatomical landmarks and the relation between neural and bony structures by offer- ing a two dimensional image of the three dimensional operative field. Due to its general availability, myelography will remain part of the diagnostic armamentarium unless a 24 hour MRI service is available.

The use of CT is not valuable for the diagnosis of intraspinal haematomas. Limitations include isointensity of haematoma to thecal sac and spinal cord and an insufficient resolution in the thoracic spine. In our series plain CT was inconclusive in four of five patients. This limits the use of CT as a non-invasive diagnostic modality. For accurate diagnosis CT has to be performed after application of an intrathecal contrast agent.

In our series MRI proved superior to the other diagnostic methods and allowed surgical planning with regard to craniocaudal extension and dorsoventral location of the lesion. Surface coil MRI permits examination in any plane without moving the patient, which is advantageous in the patient with severe pain; MRI exactly delineates the extent of cord compression and shows characteristic findings in both types of spinal haematomas. Extradural haematomas on sagittal and axial orientation have a biconvex shape ${ }^{17-19}$ (fig 1A, B). Subdural haematomas appear with concave delineation on sagittal images and irregular shape on axial images (fig 2A, B). A distinction between extradural and subdural haematoma localisation is possible on transverse T2 weighted gradient echo sequences or after the application of gadolinium-DTPA. ${ }^{20}$ Signal behaviour in MRI does not always allow a distinction between acute and chronic bleeding although T2 weighted gradient echo images are superior in demonstrating the inhomogenous signal intensity typical of haematomas examined hours after the initial bleeding. ${ }^{1620}$

\section{TREATMENT}

Management of extradural and subdural haematomas is a neurosurgical emergency. Prognosis for recovery depends on the severity and duration of neurological deficit before
Figure 1 Acute extradural haematoma in a 73 year old man (patient 6); MRI performed less than 24 hours after onset of pain irradiating into the $C 7$ dermatome and paresis of the triceps muscle. (A) Sagittal T1 weighted image $(T R=550 \mathrm{~ms}$, $T E=15 \mathrm{~ms}$ ) shows compression of the cervical spinal cord by a dorsally located, convex, and isointense space occupying lesion extending from the third cervical to the first thoracic vertebra. (B) Transverse gradient echo image $(T R=400 \mathrm{~ms}$, $T E=18 \mathrm{~ms}$, alpha $=$ $\left.15^{\circ}\right)$ demonstrates the dorsolateral left position of a lesion with low signal intensity due to the presence of

deoxyhaemoglobin (arrow).
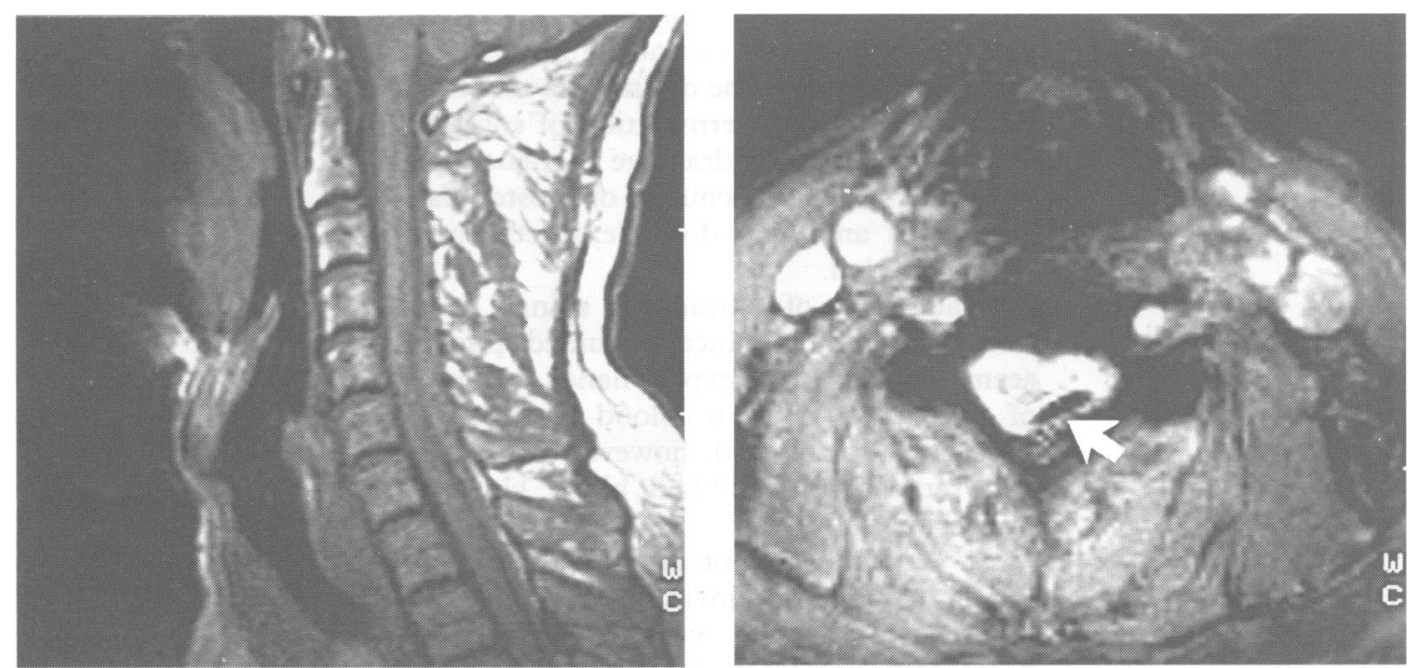

(B) 
Figure 2 Subacute subdural spinal

haematoma in a 19 year

old woman who had a

diffuse meningeal spread of

a gliomatous tumour

(patient 8). (A) The

sagittal T2 weighted image

$(T R=2400 \mathrm{~ms}, T E=$

$90 \mathrm{~ms})$ shows a high signal

intensity of the haematoma

due to the presence of

methaemoglobin. The

haematoma is located

ventrally and extends from

vertebral body Th 11 to the

sacrum. Compression and

dislocation of conus and

cauda are visible. (B) The

transverse $T 2$ weighted

image shows the

haematoma surrounding

the roots of the cauda

equina (arrows), pointing

to a subdural location of

the bleeding.

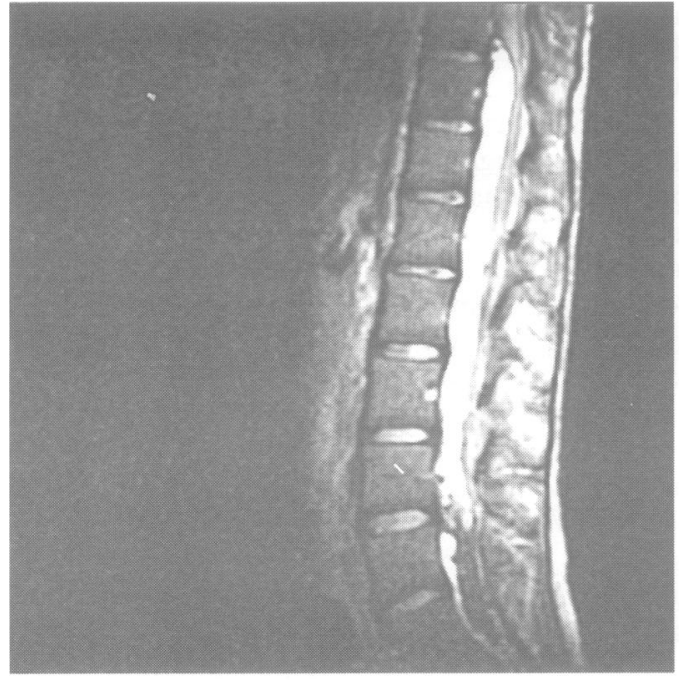

( $A)$

decompression. ${ }^{12122}$ Normalisation of prothrombin time in patients taking oral anticoagulants can be obtained by intravenous administration of fresh frozen plasma or the use of concentrates highly enriched in vitamin $\mathrm{K}$ dependent proteins. We consider a prothrombin time above $50 \%$ as sufficient for emergency surgery. Surgical decompression and evacuation of haematoma in all patients is performed through a laminectomy extending over all levels where MRI shows the presence of haemorrhage. This is necessary for two reasons: (a) unless a haematoma is completely liquified a limited approach would not allow the removal of solid clots at several spinal levels; (b) only a laminectomy might generate the space necessary to restore pulsation to the dura and spinal cord, and prevent a secondary cord compression if swelling of the myelon occurs postoperatively. If no haematoma is found epidurally or preoperative imaging points to an intradural pathology the dura is opened. The haematoma is removed with dissectors and careful suction. Before wound closure large bore suction drains are inserted between the dura and musculature and left in situ for up to three days. Care must be taken not to readapt musculature too tightly as this might cause compression of a thecal sac no longer protected by spinal laminae. The drainage is set on continuous suction on termination of surgery. If CSF is aspirated the drainage is opened intermittently. A short course of postoperative antibiotics and high dose dexamethasone is recommended.

Evacuation of extradural spinal haematomas by radiographically guided puncture seems successful in expert hands. ${ }^{23}$ The risk of iatrogenic injury to blood vessels, nerve roots, and spinal cord, however, can be high and removal of solidified blood clots even impossible.

At present it is not clear whether refinements of minimal invasive techniques will allow endoscopic evacuation of spinal haematomas, at least of those that are located extradurally. Magnetic resonance imaging

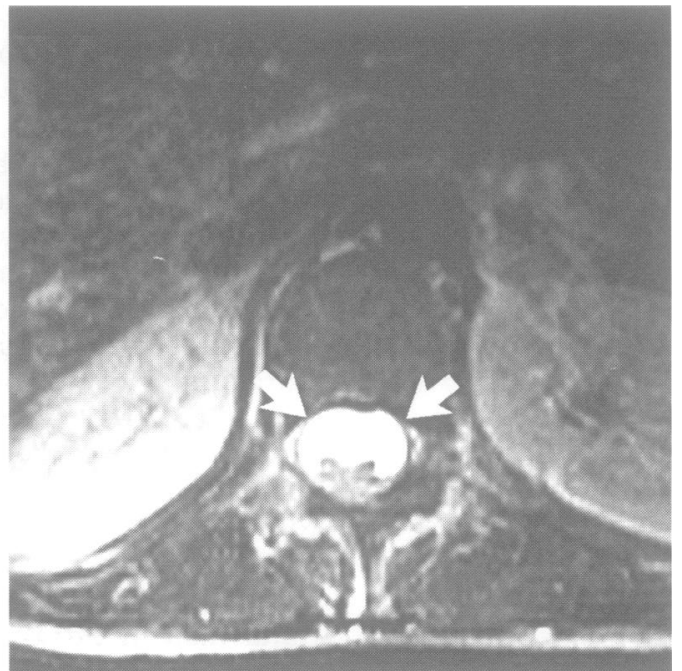

(B)

can provide information regarding haematoma localisation in relation to the dural level. The problems that occur with solidified clots and postoperative cord swelling have to be resolved satisfactorily before keyhole approaches can be advocated.

\section{PROGNOSIS}

Rapidly evacuated haematomas carry a good prognosis. Five of our patients made a full recovery. The appearance of signs of motor impairment or bladder dysfunction is critical. Treatment delays for several hours after the appearance of a complete transsection syndrome may be disastrous. Medical education must aim at those who first see a patient with suspect cord compression. ${ }^{22}$ After spinal bleeding, the signs of impaired motor function evolve over hours. If these hours are lost, referral of the patient to a surgeon who carries out decompression too often remains a desperate act.

1 Johnston RA. The management of acute spinal cord compression. I Neurol Neurosurg Psychiatry 1993;56: 1046-54.

2 Cowie RA. Acute spinal haematoma. In: Findlay G, Owen $\mathrm{R}$, eds. Surgery of the spine. Oxford: Blackwell, 1992: 823-7.

3 Bruyn GW, Bosma NJ. Spinal extradural haematoma. In: Vinken PJ, Bruyn GW, eds. Handbook of clinical neurology. Vol 13. Amsterdam: Elsevier, 1976:1-30.

4 Markham JW, Lynge HN, Stahlmann GEB. The syndrome of spontaneous spinal epidural hematoma. drome of spontaneous spin Pendl G, Ganglberger JA, Horcajada J. Das spinale epidurale Hämatom. Acta Neurochir (Wien) 1971;24:207-17.

6 Mattle H, Sieb JP, Rohner M, Mumenthaler $M$. Nontraumatic spinal epidural and subdural hematomas. Neurology 1987;37:1351-6.

7 Santa M, Sulla I, Fagula J. Spontaneous spinal epidural hematoma. Zentralblatt fur Neurochirurgie 1990;51: 164-5.

8 Flaschka G, Sutter B, Ebner F, Klein GE, Tilz G. Das pinale Epiduralhämatom. Langzeitergebnisse von 4 eigenen Fällen. Nervenarzt 1990;61:629-33.

9 Major O, Sipos L, Czirják S, Benoist G, Horváth M, Pásztor E. Spontaneous spinal epidural haematomas. Acta Neurochir (Wien) 1991;111:40-2.

10 Edelson RN. Spinal subdural hematoma. In: Vinken PJ, Bruyn GW, eds. Handbook of clinical neurology. Vol 26, Injuries of the spine and spinal cord, Pt II. Amsterdam: Injuries of the spine

11 Russell NA, Benoit BG. Spinal subdural hematoma. A review. Surg Neurol 1983;20:133-7.

12 Khosla VK, Kak VK, Mathuriya SN. Chronic spinal subdural hematomas. Report of two cases. $\not{f}$ Neurosurg 1985;63:636-9. 
13 Gingrich TF. Spinal epidural hematoma following continuing epidural anesthesia. Anesthesiology 1968;29:162-3.

14 Beatty RM, Winston KR. Spontaneous cervical epidural hematoma. A consideration of etiology. $¥$ Neurosurg hematoma. A

15 Gundry CR, Heithoff KB. Epidural hematoma of the lumbar spine: 18 surgically confirmed cases. Radiology 1993;187:427-31.

16 Larsson EM, Holtas S, Cronqvist S. Emergency magnetic resonance examination of patients with spinal cord symptoms. Acta Radiol 1988;29:69-75.

17 Bernsen PLJA, Haan J, Vielvoje GJ, Peerlinck KMJ. Spinal epidural hematoma visualized by magnetic resonance imaging. Neuroradiology 1988;30:280.

18 Avrahami E, Tadmor R, Ram Z, Feibel M, Itzhak Y. MR demonstration of spontaneous acute epidural hematoma of the thoracic spine. Neuroradiology 1989;31:89-92.
19 Di Lorenzo N, Rizzo A, Fortuna A. Spontaneous spinal epidural hematoma: preoperative diagnosis by MRI. Clin Neurol Neurosurg 1990;92:357-9.

20 Crisi G, Sorgato P, Colombo A, Scarpa M, Falasca A, Angiari P. Gadolinium-DTPA-enhanced MR imaging in the diagnosis of spinal

21 Grollmus F, Hoff J. Spontaneous spinal epidural haemorrhage: good results after early treatment. $\mathcal{f}$ Neurol Neurosurg Psychiatry 1975;38:89-90.

22 Maurice-Williams RS, Richardson PL. Spinal cord compression: delay in the diagnosis and referral of a common neurosurgical emergency. $\operatorname{Br} \mathcal{f}$ Neurosurg 1988; 2:55-60.

23 Solymosi L, Wappenschmidt J. A new neuroradiologic method for therapy of spinal epidural hematomas. Neuroradiology 1985;27:67-9.

\section{NEUROLOGY IN LITERATURE}

\section{More doctors}

The Medical profession comes off rather badly in these extracts, using whatever skills they possess for personal gain rather than for the benefit of their patients. Venality and cynicism have not disappeared from the profession although I suspect that cynicism is now more directed at the management structure of the service rather than at the humble patient. After a surfeit of neurological outpatient clinics, I suspect some neurologists would share Dr Weinrock's sentiments!

Charles Lamb, 1823, Essays. Amicus Redivivus

Monoculus-for so in default of catching his true name, I choose to designate the medical gentleman who now appeared-is a grave, middle-aged person who without having studied at the college or truckled to the pedantry of a diploma, hath employed a great portion of his valuable time in experimental processes upon the bodies of unfortunate fellow-creatures, in whom the vital spark, to mere vulgar thinking, would seem extinct, and lost for ever. He omitteth no occasion of obtruding his services, from a case of common surfeit-suffocation to the ignobler obstructions, sometimes induced by a too wilful application of the plant cannabis. Outwardly but though he declineth not altogether these drier extractions, his occupation tendeth for the most part to water-practice; for the convenience of which, he hath judiciously fixed his quarters near the grand repository of the stream mentioned, where, day and night, from his little watchtower, at the Middleton's-Head, he listeneth to detect the wrecks of drowned mortality, partly, as he saith to be upon the spot-and partly, because the liquids which he useth to prescribe to himself and his patients, on these distressing occasions, are ordinary more conveniently to be found at these common hostelries than in the shops and phials of the apothecaries.

Herman Melville, 1851, Moby Dick

"Oh! A great watcher, and very dietetically severe, is Dr Bunger. (Bunger, you dog, laugh out! why don't ye? You know you're a precious jolly rascal.) But, heave ahead, boy, I'd rather be killed by you than kept alive by any other man".

Thomas Hardy, 1886, The Mayor of Casterbridge Henchard, who treated her kindly, except in moments of irritation, sent at once for the richest, busiest doctor, whom he supposed to be the best.
Thomas Hardy, 1887, The woodlanders

Mr Fitzpiers entered the sick chamber as a doctor is wont to do on such occasions and pre-eminently when the room is that of the humble cottager; looking round towards the patient with a preoccupied gaze which so plainly reveals that he has well-nigh forgotten all about the case and the circumstances since he dismissed them from his mind at his last exit from the same apartment.

\section{$M V$ Hughes, 1934, A London child of the 1870}

The doctor himself was a dear. He saw us through all our infectious diseases and coughs, curing most of our ailments more by jollity than physic. He was specially fond of me because as he frequently said, he had saved my life. I had almost gone with measles, and when hope had practically departed he ordered champagne. I was only six years old, but I remember that champagne, and my father bringing it to $m e$ in his shirt-sleeves that hot summer evening. The very word "champagne", connected as it was with festivity, and my father's face all smiles, put new life into me, and gave me kick enough to pull through.

Henry Green, 1939, Party going

"What did he do?" she echoed, "why, what do doctors do? Of course he got his fee, Robert paid him, but you know what they are; he went away again; she might die for all he cared."

Thomas Mann, 1954, Confessions of Felix Krull: confidence man

This unworthy disciple of Aesculapius was both stupid and ambitious and had achieved his title through personal influence, exploitation of wine-house acquaintances, and the receipt of patronage; he was always going to Wiesbaden to advance his interests with the authorities. Most indicative to me was the fact that he did not receive the patients who came to his waitingroom in the order in which they arrived, but took the more influential first, letting the humbler sit and wait. His manner towards the former class was obsequious, towards the latter harsh and cynical, indicating often that he did not believe in their complaints.

foseph Heller, 1979, Good as gold

"I wouldn't take you, Bruce," Dr Weinrock answered with frankness. "Oh, I would never take on a patien who really needed help. I don't enjoy being around sick people."

G D PERKIN Regional Neurosciences Centre Charing Cross Hospital, London W6 8RF, UK 